\title{
KOMUNIKASI DALAM UPAYA PENERAPAN KEBIJAKAN PENCEGAHAN VIRUS COVID-19 DI KOTA SINGKAWANG
}

\author{
S. Y. Pudjianto ${ }^{1}$ Rasidar $^{2}$, Dea Varanida ${ }^{3}$ \\ ${ }^{1}$ Universitas Tanjungpura, Pontianak \\ ${ }^{2}$ Universitas Tanjungpura, Pontianak \\ ${ }^{3}$ Universitas Tanjungpura, Pontianak
}

Email korespondensi : dea.varanida@fisip.untan.ac.id

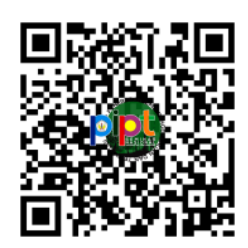

10.26418/pipt.2021.16

\begin{abstract}
Abstrak
Wabah penyakit corona virus (Covid-19) ditetapkan sebagai Kedaruratan Kesehatan Masyarakat yang telah meresahkan dan telah menyebar ke hampir seluruh negara termasuk Indonesia. Berbagai kebijakan serta himbauan telah diupayakan oleh pemerintah baik pusat hingga daerah. Semua bekerjasama dalam menghadapi peperangan melawan pandemi virus COVID-19. Maka dari itu peneliti mengkaji penerapan komunikasi kebijakan untuk pencegahan virus COVID-19 di Kota Singkawang. Konsep teori dalam penelitian ini adalah terkait implementasi kebijakan yang di dalamnya terdapat komunikasi sebagai kunci dari proses kebijakan tersebut. Jenis pendekatan yang digunakan adalah pendekatan kualitatif dianggap dapat memberikan gambaran yang komprehensif mengenai pencegahan virus Covid-19. Hasil penelitian menunjukkan bahwa penerapan kebijakan dalam pencegahan virus Covid-19 di Kota Singkawang menerapkan strategi komunikasi publiknya yaitu dalam membangun kesamaan pemahaman tentang berbagai hal yang berkaitan dengan berbagai bidang termasuk kesehatan. Berbagai penanganan telah diupayakan dalam bentuk macam-macam saluran komunikasi. untuk meningkatkan peranan komunikasi dalam upaya pencegahan Covid-19, pelaksanaan komunikasi kebijakan publik bisa dilakukan sebagai salah satu opsi usaha pemerintah untuk menangani pandemi ini. Persiapan komunikasi publik diikuti dengan penyampaian yang baik, secara langsung maupun melalui media sosial. Implementasi kegiatan upaya pencegahan Covid-19 membutuhkan peran komunikasi untuk melakukan kebijakan publik yaitu transmisi, konsistensi serta kejelasan agar menghasilkan komunikasi yang efektif.
\end{abstract}

Kata kunci: Implementasi Kebijakan Publik, Komunikasi Efektif, Covid-19

\section{PENDAHULUAN}

Saat ini dunia tengah menghadapi wabah yang sangat memberikan dampak luar biasa dalam kehidupan. Wabah ini merupakan ujian terbesar yang dihadapi oleh seluruh manusia yang ada di muka bumi. Hampir di seluruh benua terjangkit wabah virus yang masih terbilang baru di dalam bidang kesehatan. Wabah ini telah menjadi pandemi virus yang menyebabkan kelumpuhan dalam berbagai sektor. Baik itu dari ekonomi hingga pendidikan.

Wabah penyakit corona virus (COVID-19) ditetapkan sebagai Kedaruratan Kesehatan Masyarakat yang telah meresahkan dan telah menyebar ke hampir seluruh negara termasuk Indonesia. Saat ini Indonesia juga sudah memiliki pasien positif COVID-19 dan jumlahnya terbilang cukup besar untuk benua Asia. Berbagai kebijakan serta himbauan telah diupayakan oleh pemerintah baik pusat hingga daerah. Semua bekerjasama dalam menghadapi peperangan melawan pandemi virus COVID-19.

Dilansir dari berita Republika, Virus COVID-19 telah menjadi transmisi lokal, seperti yang diungkapkan oleh Gubernur Kalimantan Barat yaitu

"Kota Pontianak berdasarkan apa yang ditulis di website Kemenkes, penularan Covid-19 tidak lagi karena yang bersangkutan baru dari luar daerah atau luar negeri, tetapi penularan di Pontianak sudah dari warga ke warga, maka saya minta jangan keluar rumah, jaga jarak ketika bertemu dan selalu pakai masker," kata Sutarmidji melalui akun Facebook-nya, Kamis(26/3). "(https://republika.co.id/berita/ q7ttl1484/pontianak-jadi-pusat 
penyebaran-virus-corona-di-kalbar diakases 22 April 2020).

Maka dari itu, peneliti ingin mengkaji penerapan komunikasi kebijakan publik yang dilakukan oleh pemerintah untuk pencegahan virus COVID-19 dan juga peran masyarakat dalam berupaya mencegah virus tersebut. Karena peran dari masyarakat sangat penting dalam komunikasi kebijakan publik. Walaupun saat ini masih banyak masyarakat yang belum sepenuhnya menaati himbauan pemerintah untuk di rumah saja, baik beribadah maupun bekerja. Dilansir dari sumber yang menjadi salah satu masyarakat kota Singkawang yaitu Riki mengungkapkan masih banyak masyarakat yang memenuhi pasar hingga jalanan karena dari aspek ekonomi, yaitu dalam memenuhi kebutuhan kehidupan mereka.

Berangkat dari berbagai sumber yang ada dalam upaya pemerintah salah satunya yang berperan penting dalam menangani status darurat kesehatan ini, terdapat

masyarakat juga yang menjadi khalayak komunikan. Masyarakat dalam komunikasi kesehatan memiliki tujuan agar mereka baik kelompok atau individu dapat mengetahui informasi penting seputar masalah kesehatan dan merubah perilaku mereka agar sesuai dengan nilai-nilai kesehatan. Komunikasi kesehatan memiliki manfaat yang sangat besar baik bagi individu maupun bagi masyarakat.

Mengacu pada latar belakang yang telah diuraikan di atas, berikut merupakan pertanyaan penelitian:

1. Bagaimana penerapan komunikasi kebijakan publik yang dilakukan oleh pemerintah daerah dalam upaya untuk penanganan virus COVID -19?

2. Bagaimana kebijakan publik yang mendukung upaya penanganan virus COVID 19?

\section{TINJAUAN PUSTAKA}

\section{Komunikasi Publik}

Implementasi kebijakan sering dianggap hanya merupakan pelaksanaan dari apa yang telah diputuskan oleh legislatif atau para pengambil keputusan, seolah-olah tahapan ini kurang berpengaruh. Akan tetapi dalam kenyataannya, tahapan implementasi menjadi begitu penting karena suatu kebijakan tidak akan berarti jika tidak dapat dilaksanakan dengan baik dan benar. Dengan kata lain implementasi merupakan tahap dimana suatu kebijakan dilaksanakan secara maksimal dan dapat mencapai tujuan kebijakan itu sendiri.

Implementasi kebijakan publik juga dipengaruhi oleh beberapa faktor baik secara bersama-sama maupun sendirisendiri. George C. Edward III dalam Nurjaman dan Umam (2012 : 322) mengemukakan model implementasi kebijakan publik, yaitu :

a. komunikasi (communication),

b. sumber- sumber (resources),

c. kecenderungan atau tingkah laku (dispositions),

d. struktur birokrasi (bureaucratic structure).

Selanjutnya dijelaskan agar pelaksanaan kebijakan dapat berjalan efektif, maka kebijakan harus diketahui oleh orang-orang yang diserahi tanggung jawab untuk melaksanakannya dengan jelas, tentu saja dalam hal ini diperlukan komunikasi yang akurat dan dilaksanakan dengan tepat oleh para pelaksana. Dalam konteks implementasi kebijakan publik terdapat tiga aspek yang penting untuk mengimplementasikan sebuah kebijakan, yaitu transmisi, kejelasan, dan konsistensi.

Informasi sebagai unsur dari komunikasi mempengaruhi munculnya gangguan atau hambatan dalam implementasi kebijakan publik. Kurangnya informasi menyebabkan implementasi kebijakan publik tidak berjalan sebagaimanamestinya. Fungsi komunikasi dapat diidentikan dengan peranan komunikasi karena merujuk pada kegiatan apa yang dilakukan.

\section{Media Massa dalam Komunikasi Publik}

Media Massa adalah suatu institusi atau lembaga yang memiliki serangkaian kegiatan produksi budaya dan informasi yang dilaksanakan oleh berbagai tipe 
komunikasi massa untuk disalurkan kepada khalayak sesuai dengan kebiasaan yang berlaku. Media massa, ditinjau dari segi manfaatnya yaitu wadah untuk menyalurkan komunikasi untuk masyarakat luas atau massa

Media komunikasi secara konseptual, media komunikasi tidak sama dengan saluran komunikasi. Saluran komunikasi adalah jalan yang dilalui pesan komunikator untuk sampai ke komunikannya. Sedangkan media komunikasi adalah alat perantara yang sengaja dipilih komunikator untuk menyampaikan pesannya kepada komunikan.

Media komunikasi dapat dibedakan menjadi media tradisional dan media modern. Macam media komunikasi seperti media antar pribadi (telepon, surat) media massa (surat kabar, majalah, radio, televisi), media cetak dan media audio visual. Karakteristik media harus benar-benar dipahami dalam memilih media komunikasi, karena setiap media memiliki karakteristik yang berbeda satu dengan yang lainnya.

Komunikasi publik dalam prosesnya, terbagi menjadi dua yaitu komunikasi lisan maupun tulisan. Komunikasi publik dalam penyebutannya seringkali disebut dengan istilah komunikasi massa. Namun, dari pengertiannya komunikasi publik cenderung dinilai memiliki makna yang lebih luas dibanding dengan komunikasi massa. Lebih detail lagi, komunikasi massa merupakan komunikasi yang dalam prosesnya menggunakan suatu pesan.

\section{METODOLOGI}

Penelitian ini menggunakan pendekatan kualitatif yakni penelitian yang menurut Bodgan dan Taylor (1975) menghasilkan data deskriptif berupa kata-kata tertulis atau lisan dari orang-orang dan perilaku yang bisa diamati (dalam Moleong, 2008:4).Penelitian kualitatif bertujuan untuk menjelaskan fenomena secara mendalam dengan pengumpulan data yang dalam pula.

Metode penelitian ini dianggap paling sesuai oleh peneliti untuk memberikan gambaran yang komprehensif mengenai penerapan komunikasi kesehatan dalam pencegahan covid-19.Melalui metode ini peneliti berusaha membuat deskripsi dan analisis berbagai bentuk komunikasi kesehatan dalam upaya pencegahan virus covid-19 yang dilakukan oleh pemerintah daerah.

\section{Teknik Pengumpulan Data}

Kegiatan pengumpulan data adalah prosedur yang sangat menentukan baik atau buruknya kualitas sebuah penelitian (Kriyantono, 2010:95).Data dalam penelitian ini diperoleh melalui wawancara mendalam, observasi, dan dokumentasi.

1) Wawancara mendalam

Peneliti sebagai instrumen utama dalam penelitian kualitatif harus mampu memperoleh sebanyak-banyaknya data melalui wawancara. Dalam penelitian ini, wawancara bersifat tidak terstruktur dan terbuka. Peneliti dilengkapi pedoman wawancara (interview guide) yang sangat umum dan hanya akan mencantumkan isuisu yang harus diteliti tanpa menentukan urutan pertanyaan.

Proses menentukan informan dalam penelitian ini menggunakan teknik purposive sampling yaitu teknik pengambilan sampel sumber data dengan pertimbangan tertentu. Adapun informan dalam penelitian ini adalah unsur-unsur pemerintah, kebijakan serta peran dari masyarakat dalam upaya melakukan komunikasi kesehatan.

2) Observasi

Observasi yaitu pengumpulan data dengan melakukan pencatatan terhadap data-data yang dibutuhkan dan melakukan pengamatan terhadap situasi serta kondisi yang berhubungan dengan masalah penelitian. Sugiyono (2010:145) mengungkapkan bahwa teknik mengumpulkan data dengan observasi dilakukan bila penelitian berkenaan dengan perilaku manusia, proses kerja, gejala-gejala alam dan bila responden yang diamati tidak terlalu besar. Keunggulan dari metode pengumpulan data melalui observasi ialah data yang dikumpulkan terdapat dua bentuk, yaitu interaksi dan percakapan sehingga 
dapat diamati perilaku verbal dan nonverbal sekaligus (Kriyantono, 2010:110).

3) Dokumentasi

Dokumentasi merupakan teknik pengumpulan data dalam penelitian yang tidak pernah dapat ditinggalkan. Dokumen merupakan catatan peristiwa yang sudah berlalu (Sugiyono, 2007:82).Dokumen yang digunakan adalah semua data tertulis yang dapat berupa dokumen pribadi maupun dokumen resmi yang dimiliki informan seperti laporan pertanggungjawaban, program kerja, hasil pemeriksaan, surat keputusan, gambar, foto, dan sebagainya yang dapat dijadikan pendukung dalam penelitian.

\section{Hasil Penelitian}

Pandemi Covid-19 menyebabkan banyak kekhawatiran publik pada bidang kesehatan, tetapi selain itu yang utamanya juga adalah khawatir akan dimensi kemanusiaan, sosial dan ekonomi secara lebih luas. Banyak pihak telah melakukan berbagai upaya komunikasi secara serentak dan dalam waktu yang sama. Harapan publik adalah secara cepat dan tepat untuk mendapatkan informasi terkini. Namun masih banyak kelemahan yang terjadi salah satunya adalah pesan yang terlalu banyak dikeluarkan cenderung bersifat random dan selalu berubah.

Hal ini dapat menyebabkan gangguan dan hambatan dalam penerimaan pesan dan pada akhirnya publik sulit untuk memahami dan mengubah perilakunya. Oleh karena itu penting bagi pelaku komunikasi baik pemerintah maupun masyarakat memberi prioritas dan perhatian penuh pada tujuan perubahan perilaku masyarakat sebagai perilaku kunci yang efektif dan efisien untuk menurunkan kasus Covid-19.

Maka dari itu komunikasi publik menjadi komunikasi strategis untuk menekankan bahwa komunikasi menjadi perencanaan secara seksama dengan tujuan jangka panjang. Komunikasi publik merupakan proses pertukaran pesan dari organisasi kepada khalayak dalam bentuk komunikasi lisan maupun melalui saluran perantara.
Komunikasi publik diperlakukan sebagai komunikasi strategis untuk menjawab tantangan dari perubahan lingkungan yang disebabkan oleh Pandemi Covid-19.

Komunikasi merupakan salah satu faktor penting yang menentukan keberhasilan implementasi kebijakan publik. Kegiatan komunikasi ini sejatinya adalah untuk memastikan apakah implementasi sudah sesuai dengan isi kebijakan publiknya. "Komunikasi memang memainkan peran penting bagi berlangsungnya koordinasi dan implementasi pada umumnya." (Abdul Wahab, 1997 :77)

Melalui komunikasi kebijakan publik, pemerintah menyampaikan pesan-pesan kepada publik/ masyarakat tentang apa kegiatan-kegiatan kebijakan pemerintah dan bagaimana pelaksana tanggung jawab pemerintah kepada publik. harapan dari komunikasi kepada publik tersebut adalah lahirnya komunikasi yang efektif dan memiliki tujuan untuk memudahkan publik memahami pesan tersebut. Setelah lahirnya komunikasi yang efektif dalam komunikasi publik maka tujuan informasi yang disampaikan dapat melahirkan feedback atau timbal balik dari publik atau masyarakat.

Komunikasi publik dalam sistem pemerintahan untuk mewujudkan komunikasi yang efektif memerlukan beberapa aspek yang pertama adalah keterbukaan informasi, kedua adalah berorientasi kepada khalayak, ketiga bersikap tanggap terhadap feedback dan keempat adalah menjadikan komunikasi sebagai strategis untuk memelihara citra pemerintahan melalui pesan-pesan dalam komunikasi kebijakan publik.

Persiapan komunikasi kebijakan publik yang dilakukan oleh pemerintah Kota Singkawang tidak hanya satu arah tetapi dilakukan dengan dua arah. Komunikasi publik merupakan pertukaran pesan dengan sejumlah orang yang berada dalam sebuah organisasi atau di luar organisasi secara tatap muka ataupun melalui media. Pemerintah kota Singkawang melakukan komunikasi kebijakan publik dua arah dengan cara mendapatkan feedback atau 
timbal balik dari masyarakat dengan berbagai opsi.

Komunikasi publik tersebut tidak luput dari proses yang telah direncanakan, terprediksi dan formal. Komunikasi publik berlangsung sebagai peristiwa yang diagendakan dengan pesan, waktu, dan tempat. Namun pada saat pandemi saat ini, situasi dan kondisi dapat berubah-ubah karena yang dihadapi adalah sebuah virus yang tidak tampak dan sangat mengkhawatirkan. Jelas pemerintah harus cepat tanggap serta melakukan kegiatankegiatan yang dapat mencapai kesamaan akan pengertian terkait pesan kebijakan publik yang dikeluarkan oleh pemerintah kota Singkawang.

Meskipun efektivitas komunikasi kebijakan publik ditentukan oleh proses interaksi transaksional namun khalayak memegang peran sebagai kunci penerima yang dapat memberikan feedback dengan menaati protokol kesehatan dan melakukan social distancing. Khalayak menjadi pengontrol atas penentuan pesan yang telah diberikan oleh pemerintah sehingga khalayak atau masyarakat kota Singkawang dapat menjalani kehidupan new normal dengan baik sehingga angka konfirmasi positif Covid-19 bisa semakin menurun bahkan tidak ada lagi.

\section{Penanganan Covid-19}

Tahun 2020 merupakan tahun dengan berbagai cobaan untuk seluruh negara yang ada di dunia. Namun tidak luput juga Indonesia terkena imbas pandemi Covid-19 yang awal mulanya dengan sebutan Virus Corona. Sejak saat itu, pemerintah kota Singkawang mengumumkan akan kewaspadaan dengan virus tersebut.

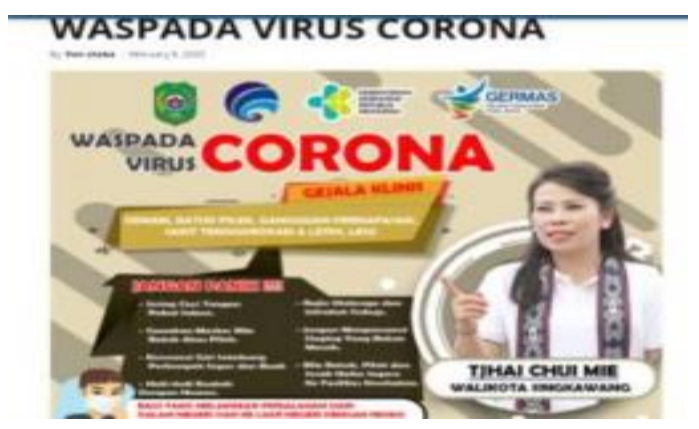

Gambar 1. Berita pertama terkait Virus Corona di awal bulan Februari 2020 (https://mediacenter.singkawangkota.go.id/waspada-viruscorona/ diakses pada tanggal 20 Agustus 2020)

Dilansir dari media center milik Kota Singkawang, pada awal Tahun tepatnya 6 Februari 2020, Ibu Walikota Thjai Chui Mie mengeluarkan himbauan untuk waspada akan virus corona tersebut, beliau menjelaskan :

"Sebelum pengumuman terdapat warga negara Indonesia dengan terkonfirmasi positif Covid-19 pada bulan Maret 2020 di Jakarta, pemerintah kota Singkawang langsung membentuk tim Satuan Gugus Tugas Quick Response Penanganan Covid19 di kota Singkawang"

Berdasarkan informasi tersebut ada respon cepat dalam mengambil langkah kebijakan untuk penanganan Covid-19 di Kota Singkawang. Di mulai dari mengambil langkah koordinasi yang disadari oleh pelaku komunikasi publik yaitu pemerintah bahwa terdapat permasalahan yang harus sesegera mungkin ditangani. Demi efektivitas penanganan yang berorientasi pada khalayak, Walikota sadar akan hakikat komunikasi publik berpusat pada khalayak atau masyarakat kota Singkawang. Di dalam komunikasi publik, pelaku komunikasi juga diharapkan dapat mampu menampilkan kompetensi yaitu sebagai pelaku komunikasi yang memiliki kredibilitas yang tinggi dalam penanganan Covid-19 tersebut. Komunikasi yang efektif menunjukkan terwujudnya

koordinasi antara pihak-pihak terkait baik pemerintah maupun stakeholder (pemangku kepentingan) seperti Dinas Kesehatan, tokoh-tokoh agama dan tokoh masyarakat. Pemerintah Kota Singkawang juga melakukan pembentukan tim gugus per kecamatan untuk dihimbau sebagai berikut. Komunikasi publik mempunyai khalayak yang terdiri dari sejumlah besar pendengar dan juga terdapat kelompok kecil yang memiliki pengetahuan yang minim, komunikasi kebijakan publik pun dapat mengakibatkan gesekan-gesekan pesan yang tidak dapat dipahami dengan baik oleh para khalayak yang dituju. Ketika terdapat masyarakat yang memiliki pemahaman yang 
keliru, maka akan berakibat timbulnya ketidakefektivan komunikasi dari pemerintah kepada masyarakat.

Salah satu upaya yang telah dilakukan untuk penanganan adalah memberikan edukasi masyarakat melalui bentukan tim per kecamatan. Memberikan pengetahuan kepada masyarakat agar memiliki pemahaman yang baik dan akhirnya memberikan sikap yaitu melaksanakan disiplin terhadap protokol kesehatan diperlukan alat dan juga teknik komunikasi. Apalagi ketika pandemi saat ini, banyak istilah-istilah baru yang tidak semua dapat dipahami dengan baik oleh masyarakat. Untuk menyampaikan edukasi tersebut juga harus melalui berbagai saluran komunikasi kepada masyarakat secara tepat, cepat, obyektif, berkualitas baik, berwawasan nasional, dan mudah dimengerti terkait dengan kebijakan dan program pemerintah.

Ibu Tjhai juga memberikan penuturan seperti ini dalam memberikan edukasi dalam salah satu penanganan penempatan tempat karantina secara langsung kepada masyarakat:" Saya menjadi Walikota ini bisa diibaratkan menjadi orang tua, saya mau tanya dulu mana ada orang tua mau bawa barang buruk ke dalam rumah untuk merusak anak-anaknya. Paling penting ini edukasi kepada masyarakat dan juga tokohtokoh agama yang penting adalah edukasi pencegahan dan penyebaran. Setiap rapat penanganan pasti kita undang baik tokoh masyarakat maupun tokoh agama walaupun tidak masuk secara langsung masuk ya"

Dalam komunikasi publik, penerima pesan mempunyai kedudukan yang sentral karena memegang kendali dan mempunyai tujuan untuk memberikan dampak kepada khalayak. Dampak dari edukasi yang dilakukan adalah timbulnya inisiatif dari berbagai elemen masyarakat contohnya adalah bantuan dari aliansi para pengusaha baik yang

berada di kota Singkawang, ataupun yang berada di luar kota tetapi merupakan warga asli kota Singkawang.

Dapat dilihat bahwa timbul kesadaran untuk bekerja sama dengan baik kepada pihak pemerintah. Hal ini tidak terlepas dari peran pemerintah yang sudah melaksanakan komunikasi publik dengan melakukan komunikasi yang strategis melalui pesan komunikasi publik. Pesan komunikasi yang diberikan oleh pemerintah kota Singkawang dalam penanganan Covid-19 mampu merangsang pihak-pihak secara mandiri menginisiasi pergerakan dalam membantu penanganan, ini merupakan pembuktian pesan yang diberikan sudah efektif. Pesan yang disampaikan juga melalui banyak saluran media guna menghasilkan feedback atau timbal balik dengan wujud understanding atau pemahaman yang baik sehingga menghasilkan sikap yang sesuai dengan pesan komunikasi publik tersebut. Salah satunya menggunakan teknologi dalam berkomunikasi, seperti pemanfaatan smartphone untuk menyebarluaskan informasi melalui media online dan media sosial.

Strategi komunikasi publik yang dilakukan oleh Pemerintah dalam koordinasi penanganan Covid-19. Dalam penyampaian informasi dilakukan secara intensif hingga masuk ke setiap grup Whatsapp juga diutarakan oleh Ibu Thjai berikut ini :

"Komunikasi tidak hanya administratif, ada juga tim WA Group milik Gugus Tugas, ada Tim Inti dan satu lagi Tim Singkawang Peduli Covid ini campuran ada pengusaha dan lain-lain. Jadi koordinasi langsung di group sehingga seperti galang dana. Ada juga satu Tim Relawan Panitia Covid Singkawang, ini tim relawan.

Harapan dalam komunikasi melalui media masa tersebut adalah dapat melakukan komunikasi koordinasi secara intensif. Dalam komunikasi publik, jika pengelolaan komunikasi dilakukan dengan optimal maka informasi kebijakan dan program kerja Pemerintah dapat terealisasi dengan baik. Dan sebaliknya, jika komunikasi publik tidak diiringi dengan strategi yang baik maka upaya dalam menghadapi permasalahan apalagi saat pandemi saat ini akan mudah mengakibatkan sikap masyarakat yang tidak diharapkan. 
Peneliti juga menemukan bahwa masih ada masyarakat khususnya anak-anak remaja yang masih belum aware terhadap penanganan Covid-19 di Kota Singkawang. Hal ini dibuktikan dengan hasil survey dan dokumentasi oleh peneliti.

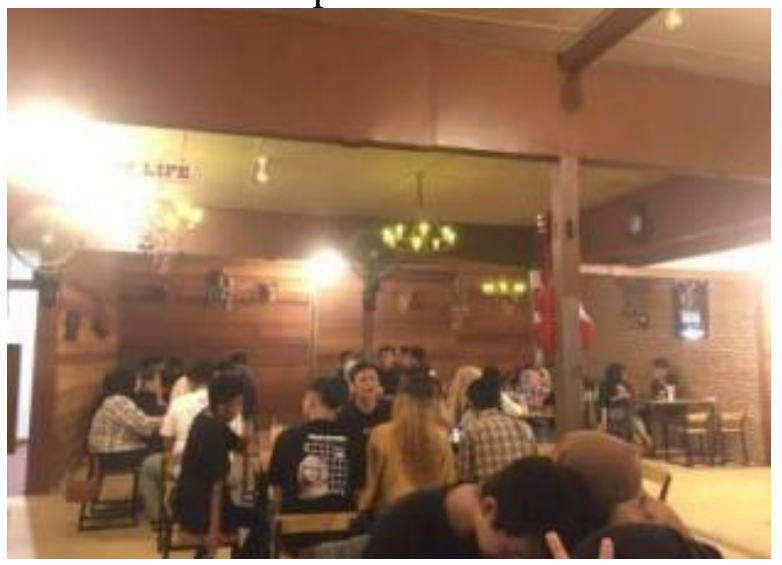

Gambar 2. Dokumentasi Peneliti

Dari hasil dokumentasi peneliti di atas, maka bisa terlihat dengan jelas beberapa remaja yang tidak menggunakan masker pada saat melakukan kontak atau komunikasi dengan orang lain. Hal ini tidak sejalan dengan kebijakan publik yang sudah di komunikasikan oleh pemerintah kota Singkawang. Namun, dari kacamata peneliti yang telah melakukan observasi dengan melihat situasi dan kondisi secara langsung, memang masih sangat banyak masyarakat yang masih belum mematuhi protokol kesehatan.

Seperti yang telah dilansir dari penuturan di atas adalah melalui stakeholder yang merupakan pihak internal dan eksternal perusahaan, seperti pemerintah, perusahaan pesaing, masyarakat sekitar, lingkungan internasional, lembaga luar perusahaan (LSM dan semacamnya), kaum minoritas dan semacamnya (Hadi Nor,2011). Beberapa stakeholder dari pemerintah sudah melakukan berbagai upaya penanganan dengan koordinasi antar kepala kelurahan dan juga instansi yang terkait yaitu BPBD. Namun masyarakat menjadi khalayak sasaran utama dalam penanganan Covid-19. Maka dari itu, peneliti mencoba untuk menelusuri lebih dalam terkait oknum masyarakat yang masih tidak patuh akan kebijakan dari pemerintah. Peneliti melakukan survey kepada 12 orang remaja berusia 18-25 tahun yang terdiri dari 6 orang laki-laki dan 6 orang perempuan. Hasil yang di dapat adalah sebagai berikut :

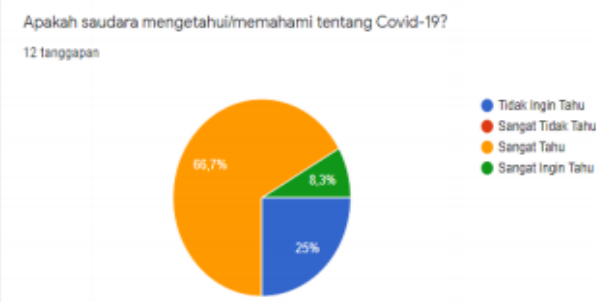

Gambar 3. Hasil diagram jawaban remaja Kota Singkawang

(Olahan Peneliti, 2020)

Peran Media Massa dalam Komunikasi Kebijakan Publik Komunikasi Kebijakan publik akan dilihat terhadap konsistensi daripada implementasi kebijakan komunikasi publik ini, dengan target bahwa pemberitaan haruslah update, terkait kasus konfirmasi positif, angka kesembuhan, angka kematian dan juga sosialisasi penanganan dalam upaya mencegah penularan virus Covid-19. Hal ini menunjukkan kesinambungan dari implementasi tersebut.

Dilansir dari penuturan Bapak Lurah Kampung Melayu yaitu menggunakan berbagai media sosial dari Facebook, Instagram, dan juga Youtube dalam melakukan komunikasi kebijakan publik kepada masyarakat dalam rangka menghimbau taat dan patuh kepada protokol kesehatan. Contohnya seperti ini :

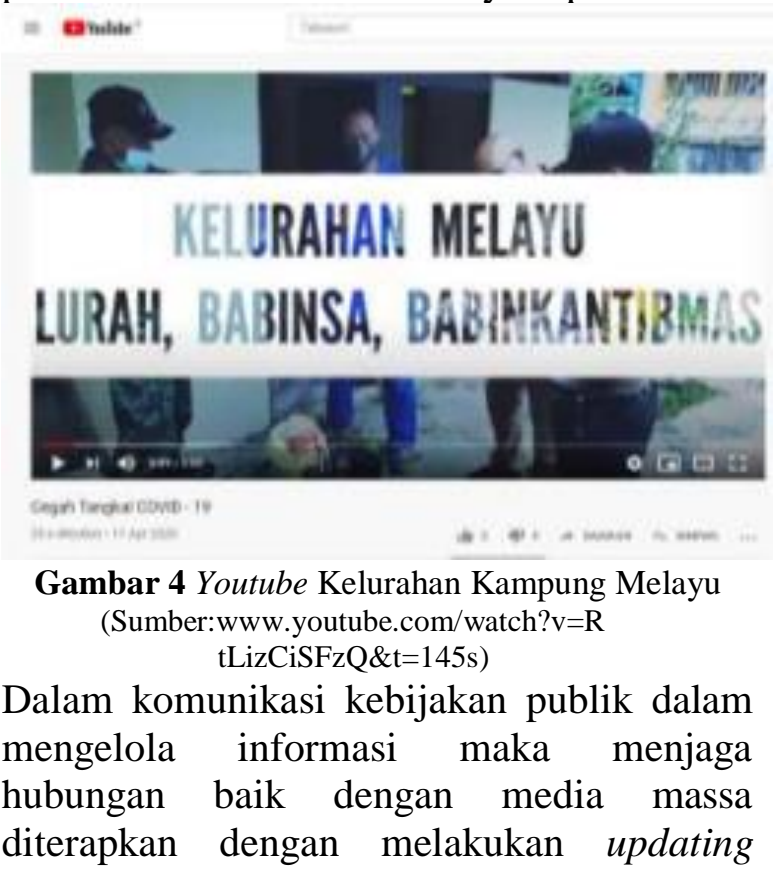


issue. Juga hubungan baik dengan masyarakat melalui media sosial, yang ditampilkan adalah mengenai pemberitaan yang menarik hati masyarakat, sehingga diharapkan masyarakat dapat pengetahuan yang benar, pemahaman yang baik serta sikap yang paling penting guna untuk melihat hasil kebijakan publik sudah berhasil atau tidak sehingga capaian kebijakan publik dapat tercapai.

Dari berbagai pembahasan terkait hasil penelitian dalam upaya penanganan Covid19 di kota Singkawang, media sosial memang yang paling menjadi opsi alternatif paling aksesibel dan efektif serta efisien. Apalagi saat pandemi saat ini yang kita senantiasa dihimbau untuk melakukan WFH (Work From Home) serta menghindari kerumunan agar menjaga himbauan terkait social distancing.

Analisa pendekatan Stakeholder Theory menjelaskan bahwa melalui komunikasi publik yang intensif dan konsisten kepada masyarakat sebagai khalayak sasaran dalam upaya mematuhi protokol kesehatan, sangat tepat dilakukan agar pencegahan penularan virus ini dapat kita atasi secara bersama. Karena saat ini kita sedang menghadapi perang terhadap hal yang tidak tampak maka dari itu, berbagai upaya dari kebijakan publik yang harus diiringi dengan komunikasi publik yang baik serta penggunaan media sosial sebagai saluran komunikasi publik dari pemerintah kepada masyarakat.

Berbagai kanal media massa telah digunakan dalam upaya memberikan informasi kepada masyarakat kota Singkawang untuk memenuhi tiga pilar dalam komunikasi kebijakan publik. Yang pertama adalah agar masyarakat memiliki pengetahuan yang benar dan tidak termakan oleh teori-teori serta informasi menyimpang yang dapat menyebabkan pemahaman yang salah sehingga tidak akan terjadi ketidakpercayaan masyarakat terhadap pemerintah. Dalam komunikasi publik juga hal ketiga yang menjadi sebuah simbol dari understanding dalam komunikasi ialah sikap atau hasil dari pengetahuan dan pemahaman komunikasi publik yang telah dilakukan oleh pemerintah kota Singkawang dengan wujud kepatuhan akan protokol kesehatan.

\section{KESIMPULAN}

Berhasilnya implementasi kebijakan pencegahan dan pengendalian corona virus disease 2019 di Kota Singkawang disebabkan oleh faktor komunikasi yang telah ditransmisikan secara jelas dan konsisten, disertai dengan komitmen yang tinggi yakni taat asas, penuh rasa tanggungjawab dan semangat kerja yang tinggi dari para implementor dan instansi terkait. Penanganan Covid-19 di kota Singkawang merupakan upaya yang aksesibel, efektif serta efisien. Pemerintah menerapkan strategi komunikasi publiknya yaitu dalam membangun kesamaan pemahaman tentang berbagai hal yang berkaitan dengan berbagai bidang termasuk kesehatan. Berbagai penanganan telah diupayakan dalam bentuk macam-macam saluran komunikasi.

Strategi yang pertama adalah koordinasi antar instansi yaitu Badan Penanggulangan Bencana Daerah (BPBD), seluruh kelurahan yang ada di kota Singkawang, tokoh agama, tokoh masyarakat, pengusaha Kalbar, dan juga tim relawan yang bersedia membantu dengan ikhlas untuk bekerjasama dengan pemerintah dalam melakukan penanganan Covid-19. Strategi yang kedua adalah pemerintah kota Singkawang juga melakukan komunikasi kebijakan publik. dengan dua arah yaitu dengan cara mendapatkan feedback atau timbal balik dari masyarakat dengan berbagai opsi. Opsinya adalah dari berbagai tim yang telah dibentuk yaitu Kampung Siaga Covid-19 yang dibentuk per kelurahan. Walikota juga selalu memastikan adanya kepatuhan bersama yang dilaksanakan dengan melakukan edukasi kepada masyarakat terkait protokol kesehatan dengan menerima laporan secara berkala. 
Oleh karena itu, sesuai dengan pernyataan jawaban remaja yang menjadi responden untuk mengisi survey yang telah dibuat oleh peneliti. Alasan kami memilih remaja adalah dari hasil observasi sebagian besar masyarakat yang belum patuh adalah para remaja terbilang umur 18-25 tahun. Usia remaja tersebut terbilang sangat produktif, tingkat aktivitas mereka sangat tinggi. Akan tetapi ketidakpercayaan kepada virus Covid-19 terbilang sangat rendah dan juga narasi komunikasi kebijakan publik yang dilakukan oleh pemerintah yang cenderung tidak konsisten membuat mereka semakin tidak percaya sehingga terjadi ketidakpatuhan akan protokol kesehatan.

\section{SARAN}

Sehubungan dengan kesimpulan di atas, disarankan agar kegiatan-kegiatan dievaluasi secara seksama sehingga pengoperasiannya dapat berlangsung sesuai dengan tujuan capaiannya Dan juga, diperlukan adanya komunikasi dan koordinasi yang intensif antara pemerintah dan masyarakat yang bisa terwakili oleh ketua RT, Lurah maupun camat masingmasing di kota Singkawang daerah.

Di samping itu, untuk meningkatkan peranan komunikasi dalam upaya pencegahan Covid-19, pelaksanaan komunikasi kebijakan publik bisa dilakukan sebagai salah satu opsi usaha pemerintah untuk menangani pandemi ini. Persiapan komunikasi publik diikuti dengan penyampaian yang baik, secara langsung maupun melalui media sosial. Implementasi kegiatan upaya pencegahan Covid-19 membutuhkan peran komunikasi untuk melakukan kebijakan publik yaitu transmisi, konsistensi serta kejelasan agar menghasilkan komunikasi yang efektif. Komunikasi yang efektif memudahkan orang lain dalam memahami pesan yang disampaikan oleh komunikator.

Rekomendasi kebijakan, membuat kebijakan baru yang berkaitan dengan komunikasi publik yang diarahkan untuk pencerahan dan mendidik sesuai dengan kondisi masyarakat
Singkawang agar protokol kesehatan menjadi bagian hidup mereka bukan karena anjuran dari pemerintah. Kebijakan yang dapat diterapkan oleh pengambil kebijakan adalah lebih banyak melakukan narasi tunggal khususnya terhadap upaya pencegahan Covid-19 agar berita negatif selama pandemi semakin berkurang lagi. Dengan dua arah yaitu dengan cara mendapatkan feedback atau timbal balik dari masyarakat dengan berbagai opsi.

Opsinya adalah dari berbagai tim yang telah dibentuk yaitu Kampung Siaga Covid-19 yang dibentuk per kelurahan. Walikota juga selalu memastikan adanya kepatuhan bersama yang dilaksanakan dengan melakukan edukasi kepada masyarakat terkait protokol kesehatan dengan menerima laporan secara berkala. Strategi yang ketiga adalah pihak pemerintah yang diwakili oleh Ibu Walikota Singkawang selalu melakukan koordinasi dengan ikatan pengusaha Kalbar. Oleh karena itu, hampir di setiap toko terdapat tangki- tangki untuk mencuci tangan yang menjadi salah satu protokol kesehatan pada saat pandemi sekarang ini. Strategi berikutnya adalah dengan menggunakan media massa. Media massa dianggap aksesibel karena mudahnya akses menggunakan internet dan juga terbilang efektif serta efisien dalam manajemen waktu. Hal yang dilakukan oleh pemerintah dalam upaya penanganan adalah memberikan

informasi secara berkala baik melalui website, instagram, facebook, dan kanalkanal media massa yang ada.

\section{DAFTAR PUSTAKA}

Bungin, Burhan. 2008. Analisis Data Penelitian Kualitatif: Pemahaman Filosofis dan Metodologis ke Arah Penguasaan Model Aplikasi. Jakarta: Rajawali Pers.

Creswell, John W. 2010. Research Design: Pendekatan kualitatif, kuantitatif, dan Mixed. Yogyakarta; Pustaka Pelajar. 
Dye, Thomasd R. 2000. Understanding Public Policy. New York: Perentice Hall.

Edward III, George C. 1980. Implementing Public Policy. Washington: Congressional Quarterly Press.

Graeff, Judith A., John P. Elder., \& Elizabeth Mills Booth. (1996). Komunikasi untuk Kesehatan dan Perubahan Perilaku (terjemahan). Yogyakarta: Gadjah Mada University Press.

Hadi, Nor. 2011. Corporate Social Responsibility. Yogyakarta: Graha. Johns Hopkins Bloomberg School of Public Health, Universitas Indonesia, dan USAID.(2005). Panduan Lapangan Merancang Strategi Komunikasi Kesehatan. Jakarta: Program STARH.

Kriyantono, Rachmat. 2010. Teknik Praktis Riset Komunikasi. Jakarta: Kencana. Moleong, Lexy J. 2008. Metode Penelitian Kualitatif. Bandung: Remaja Rosdakarya.

Mulyana, Deddy. 2014. Ilmu Komunikasi: Suatu Pengantar. Bandung: PT. Remaja Rosdakarya.
Notoatmodjo, Soekidjo. (2005). Promosi Kesehatan Teori dan Aplikasi. Jakarta: Rineka Cipta.

Nurjaman, K. \& Umam, K. (2012). Komunikasi dan Public Relations. Bandung: Penerbit Pustaka Setia.

Rakhmat, Jalaludin. 2009. Metode Penelitian Komunikasi. Bandung: PT Remaja Rosdakarya

Sugiyono. 2007. Memahami Penelitian Kualitatif. Bandung: Alfabeta.

UNICEF, (2020). Pesan dan Kegiatan Utama Pencegahan dan Pengendalian COVID 19 di Sekolah. Education in Emergencies UNICEF New York.

West Richard. Pengantar Teori Komunikasi: Teori dan Aplikasi. (Jakarta: Salemba Humanika, 2008)

\section{Internet}

https://republika.co.id/berita/q7ttl1484/ponti anak-jadi-pusat-penyebaran-viruscorona di-kalbar 